\title{
Repeated Cocaine Administration Induces Gene Expression Changes through the Dopamine DI Receptors
}

\author{
Dongsheng Zhang', Lu Zhang', Yang Tang', Qi Zhang', Danwen Lou', Frank R Sharp², Jianhua Zhang' \\ and Ming $\mathbf{X u}^{*}$, I \\ 'Department of Cell Biology, Neurobiology and Anatomy, University of Cincinnati College of Medicine, Cincinnati, OH, USA; ${ }^{2}$ Department \\ of Neurology, University of Cincinnati College of Medicine, Cincinnati, OH, USA
}

\begin{abstract}
Drug addiction involves compulsive drug-seeking and drug-taking despite known adverse consequences. The enduring nature of drug addiction suggests that repeated exposure to abused drugs leads to stable alterations that likely involve changes in gene expression in the brain. The dopamine DI receptor has been shown to mediate the long-term behavioral effects of cocaine. To examine how the persistent behavioral effects of cocaine correlate with underlying changes in gene expression, we have used DI receptor mutant and wild-type mice to identify chronic cocaine-induced gene expression changes mediated via the DI receptors. We focused on the caudoputamen and nucleus accumbens, two key brain regions that mediate the long-term effects of cocaine. Our analyses demonstrate that repeated cocaine administration induces changes in the expression of 109 genes, including those encoding the stromal cell-derived factor I, insulin-like growth factor binding protein 6, sigma I receptor, regulators of G-protein signaling protein 4, Wnt I responsive Cdc42 homolog, $\mathrm{Ca}^{2+} /$ calmodulin-dependent protein kinase II $\alpha$ subunit, and cyclin D2, via the DI receptors. Moreover, the seven genes contain AP-I binding sites in their promoter regions. These results suggest that genes encoding certain extracellular factors, membrane receptors and modulators, and intracellular signaling molecules, among others, are regulated by cocaine via the DI receptor, and these AP-I transcription complex-regulated genes might contribute to persistent cocaine-induced behavioral changes. Neuropsychopharmacology (2005) 30, |443-1454, advance online publication, I6 March 2005; doi: I0.1038/sj.npp. I 300680
\end{abstract}

Keywords: chronic cocaine; dopamine DI receptor; gene expression; AP-I transcription complex

\section{INTRODUCTION}

Drug addiction is characterized by the compulsive seeking and taking of drugs despite adverse consequences (Leshner, 1997). A cardinal feature of this brain disease is that it is long-lasting (Koob et al, 1998; White and Kalivas, 1998; Berke and Hyman, 2000; Nestler, 2001; Hyman and Malenka, 2001). The neurobiological basis underlying the effects of cocaine is associated with the brain dopaminergic system that consists of dopamine (DA) neurons originating in the midbrain region and projecting to multiple brain areas including the nucleus accumbens (NAc) and caudoputamen (CPu; Koob, 1992). Abused drugs can increase synaptic levels of DA that is involved in reward and reinforcement (Ritz et al, 1987; Koob, 1992; White and

\footnotetext{
*Correspondence: Dr M Xu, Department of Cell Biology, Neurobiology and Anatomy, University of Cincinnati Medical Center, Cincinnati, OH 45267-052I, USA, Tel: + I 513558 2922, Fax: + I 513558 4454, E-mail: ming.xu@uc.edu

Received 9 September 2004; revised 10 December 2004; accepted 15 December 2004

Online publication: 4 January 2005 at http://www.acnp.org/citations/ Npp0 I04050404 I I/default.pdf
}

Kalivas, 1998; Hyman and Malenka, 2001; Nestler, 2001; Kelley and Berridge, 2002; Everitt and Wolf, 2002).

The DA D1 receptor is expressed in multiple brain regions, including the $\mathrm{CPu}$ and $\mathrm{NAc}$, areas that mediate the effects of cocaine (Civelli et al, 1993; Gingrich and Caron, 1993; Sibley et al, 1993; Missale et al, 1998). The D1 receptor interacts with $G_{s}$ proteins, and stimulation of the receptor leads to increased intracellular levels of cAMP, resulting in the activation of a transcription factor, the cAMP-response element binding protein (CREB; Civelli et al, 1993; Gingrich and Caron, 1993; Sibley et al, 1993; Missale et al, 1998). Activated CREB can regulate the expression of cellular genes including the immediate-early gene (IEG) c-fos (Nestler, 2000, 2001). The D1 receptor plays a critical role in mediating the behavioral and cellular effects of cocaine. For example, D1 receptor agonists and antagonists can affect cocaine-induced locomotor responses, discriminative stimulus, reinforcing effects, and reinstatement in a variety of experimental animal systems (Cabib et al, 1991; Caine and Koob, 1994; Tella, 1994; Cervo and Samanin, 1995; Pruitt et al, 1995; Self et al, 1996; Grech et al, 1996; Baker et al, 1998; Tzschentke, 1998; Caine et al, 1999, 2000; Katz et al, 1999; Khroyan et al, 2000; Anderson et al, 2003; Nazarian et al, 2004). Repeated cocaine injections also lead to persistent increases in D1 receptor sensitivity within the 
NAc (Henry and White, 1995). We have used the D1 receptor mutant mice and showed that this receptor mediates the locomotor sensitization and rewarding effects of cocaine (Xu et al, 1994a, b, 2000; but see Miner et al, 1995).

The persistent nature of drug addiction suggests that repeated exposure to abused drugs leads to enduring alterations that likely involve gene expression changes in the brain (Koob et al, 1998; White and Kalivas, 1998; Berke and Hyman, 2000; Nestler 2000, 2001; Hyman and Malenka, 2001). Changes in gene expression through the D1 receptors may contribute to neuroadaptations to chronic exposure to cocaine (Graybiel et al, 1990; Koob et al, 1998; White and Kalivas, 1998; Berke and Hyman, 2000; Nestler, 2000, 2001; Hyman and Malenka, 2001). Much evidence suggests the involvement of the Fos family proteins and CREB in mediating the effects of cocaine. For example, acute cocaine injections induce c-Fos and CREB expression via the D1 receptors, and the expression returns to the baseline hours later (Graybiel et al, 1990; Moratalla et al, 1996; Zhang et al, 2002, 2004). Repeated cocaine administration induces relatively long-lasting AP-1 transcription complexes consisting of $\triangle \mathrm{FosB}$ also via the D1 receptors (Nestler et al, 1999; Zhang et al, 2002). Persistent $\Delta$ FosB expression in D1 receptor-producing neurons in the NAc in mice can increase the locomotor-stimulating and rewarding effects of cocaine (Kelz et al, 1999; Colby et al, 2003). Increased expression of CREB is associated with a decrease in the rewarding effects of cocaine (Carlezon et al, 1998). These observations imply that Fos family protein- and CREBregulated gene expression may contribute to neuroadaptations to repeated exposure to cocaine.

Drug addiction involves neuroadaptations that likely include complex changes in gene expression. The microarray method allows high-throughput analysis of gene expression patterns (Khan et al, 1999; Lipshutz et al, 1999), and it is particularly useful for studying cocaineinduced gene expression changes (Bibb et al, 2001; Freeman et al, 2001a, b; Toda et al, 2002; McClung and Nestler, 2003; Yuferov et al, 2003; Tang et al, 2003; Yao et al, 2004; Albertson et al, 2004). Despite these studies, the gene expression profile induced by chronic cocaine through the DA D1 receptors remains unclear. To address this issue, we have used the Affymetrix oligonucleotide genechips to identify gene expression differences in D1 receptor mutant and wild-type mice that exhibit differences in chronic cocaine-induced behavioral changes $24 \mathrm{~h}$ after cocaine withdrawal. We then focused on confirming the differential expression of selected candidate genes in the two groups of mice. Our analyses demonstrate that repeated cocaine administration induces changes in the expression of several groups of cellular genes that contain AP-1 binding sites in their promoter regions, suggesting that these AP-1 transcription complex-regulated genes in D1 receptor-producing neurons contribute to persistent cocaine-induced behavioral changes.

\section{MATERIALS AND METHODS}

\section{Mice}

The D1 receptor mutant mice were previously generated and have been back-crossed from the initial C57BL/
6Jx129Sv genetic background with wild-type C57BL/6J mice for three generations (Xu et al, 1994a). Mutant and wildtype littermates were derived from heterozygous breeding and were genotyped by Southern blotting (Xu et al, 1994a). All mice were housed in a room on a $12 \mathrm{~h}$ light/dark cycle with food and water available ad libitum. The temperature and humidity of the room were controlled.

\section{Drug}

Cocaine hydrochloride and SCH23390 (Sigma, St Louis, MO) were dissolved in saline. Cocaine was used at $30 \mathrm{mg} / \mathrm{kg}$ for acute injections or at $20 \mathrm{mg} / \mathrm{kg}$ for repeated injections. $\mathrm{SCH} 23390$ was used at $0.5 \mathrm{mg} / \mathrm{kg}$. Saline was injected in equal volumes as $0 \mathrm{~h}$ controls. All injections were administered intraperitoneally (i.p.) in $1 \mathrm{ml} / 0.1 \mathrm{~kg}$ body weight volumes during the light phase of the light/dark cycle (Xu et al, 2000).

\section{Treatment Paradigms}

Three treatment paradigms were used in the current study. The chronic injection paradigm, which was described previously (Xu et al, 2000; Zhang et al, 2002), was used to identify and verify repeated cocaine-induced and D1 receptor-mediated gene expression changes. D1 receptor mutant and wild-type mice 6-10 weeks of age (mean age was 7.8 weeks) were injected twice daily i.p. at 1100 and 1600 for 7 days with either $20 \mathrm{mg} / \mathrm{kg}$ of cocaine or saline as $0 \mathrm{~h}$ controls. While cocaine-treated wild-type mice exhibited increased locomotor stimulation during the injection time window, D1 receptor mutant mice failed to do so (Xu et al, 2000; Zhang et al, 2002). The use of the $20 \mathrm{mg} / \mathrm{kg}$ dose of cocaine avoided lethality of mice, which occurred when $30 \mathrm{mg} / \mathrm{kg}$ of cocaine was used. In the acute injection paradigm, D1 receptor mutant and wild-type mice were given one cocaine injection at the $30 \mathrm{mg} / \mathrm{kg}$ dose or saline as $0 \mathrm{~h}$ controls to compare acute cocaine-induced gene expression changes in the two groups of mice. The D1 receptor antagonist paradigm was used to compare the effects of D1 receptor gene mutation with pharmacological blockade of the D1 receptor on cocaine-induced gene expression changes. Four groups of wild-type mice were given two injections twice daily as follows: saline + saline, SCH23390 + saline, SCH23390 + cocaine, or saline + cocaine. SCH23390 or saline was administered $30 \mathrm{~min}$ before cocaine or saline injections. Unless indicated, identical numbers of male and female mice from each genotype were used for each condition.

\section{RNA Isolation}

To identify chronic cocaine-induced gene expression changes shortly after withdrawal, we focused on the $\mathrm{CPu}$ where robust cocaine-induced molecular changes occur (Berke et al, 1998). To avoid identifying acute cocaineinduced genes, such as the IEGs (Zhang et al, 2002, 2004), and to reduce noise including stress-induced genes, we isolated total RNA from the treated mice $24 \mathrm{~h}$ after the last injection. We used saline-treated D1 receptor mutant mice and wild-type mice to control for baseline differences. 
For microarray hybridizations, chronic cocaine- and saline-treated mice $(n=12$ each) were decapitated and $\mathrm{CPu}$ tissues were dissected and homogenized individually in TRIZOL (Life Technology, Rockville, MD). After the extraction, total RNA was precipitated by isopropyl alcohol, washed with $70 \%$ ethanol, and dissolved in water. OD readings at 260 and $280 \mathrm{~nm}$ were determined and the ratio was between 1.9 and 2.1. The quality of the total RNA was further examined by gel electrophoresis and by Agilent 2001 Bioanalyzer (Agilent, Palo Alto, CA), and the two methods showed clear bands and peaks, respectively, indicating that no degradation occurred during isolation.

For quantitative real-time polymerase chain reactions (RT real-time PCR), both the chronic and acute injection paradigms were used. At $2 \mathrm{~h}$ after either acute cocaine or saline injections, or $24 \mathrm{~h}$ after the last chronic cocaine or saline injection, intact brains ( $n=4$ each at each time point) were removed and the $\mathrm{CPu}$ tissues were isolated. Total RNA was isolated with TRIZOL reagent, precipitated, and subjected to further purification using a DNA free kit (Ambion, Austin, TX). The quality and quantity of extracted total RNA samples were examined by using a spectrophotometer and gel electrophoresis, respectively, as described previously.

\section{Microarray Processing and Data Analysis}

Sample labeling, microarray hybridization, and image scanning were carried out according to the Affymetrix Expression Analysis Technical Manual. A $10 \mu \mathrm{g}$ portion of total RNA from individual mice was used to synthesize cDNAs that were used as templates to generate biotinylated cRNA. cRNA was fragmented and hybridized to Affymetrix mouse U74Av2 genechips that contain probe sets for more than 12000 genes and ESTs. The genechips were washed and scanned with a laser scanner (Agilent, Palo Alto, CA). The Affymetrix GENECHIP software (MAS 5.0) was used to calculate the raw expression value of each gene from the scanned image. RNA quality was further examined by the $3^{\prime}$ to $5^{\prime}$ ratios for actin and glyceraldehyde-3-phosphate dehydrogenase. Samples were excluded if the ratio was greater than 2, or if there were visible defects on the arrays, or if the hybridization was much weaker or stronger than most other arrays. Hybridizations were performed three times for each of the four treatment conditions using RNA isolated from different mice.

A linear scaling procedure was performed so that signal intensities for all genes on an array are multiplied by a scaling factor that makes the average intensity value for each array equal to a preset value of 1500 . This procedure scaled the average intensity of all the arrays to the same level and made the comparison among different samples possible. The two-way ANOVA tool of GeneSpring 6.0 was used to identify genes that are differentially regulated among four groups of mice: saline-treated D1 receptor mutant mice, chronic cocaine-treated D1 receptor mutant mice, saline-treated wild-type mice, and chronic cocainetreated wild-type mice, with treatment (cocaine or saline) as one parameter and genotype (D1 receptor mutant or wild type) as the second parameter. Using this test, we identified genes that are differentially expressed due to the genotype or cocaine treatment and also determined if there is any interaction between the two parameters. $p<0.05$ was considered as significant. Based on this criterion, we used a cutoff of at least a 1.2-fold difference in expression for further studies.

\section{Quantitative Real-Time PCR}

RETROscript $^{\mathrm{TM}}$ (Ambion, Austin, TX) was used to reverse transcribe RNA to cDNA. A $2 \mu \mathrm{g}$ portion of total RNA was mixed with oligo $(\mathrm{dT})$ or random decamers $(5 \mu \mathrm{M})$, and denatured. The cDNA synthesis was carried out at $42^{\circ} \mathrm{C}$ for $1 \mathrm{~h}$ using $100 \mathrm{U}$ of Moloney murine leukemia reverse transcriptase, $10 \mathrm{U}$ of RNase inhibitor, and $500 \mu \mathrm{M}$ of dNTPs in a $20 \mu 1$ volume (Vincent et al, 2002). Quantitative real-time PCR was performed using the LightCycler-DNA Master SYBR Green I kit (Roche, Mannheim, Germany). Primers were designed using Primer3 (Whitehead Institute for Biomedical Research, Cambridge, MA) for genes encoding the D1 receptor, stromal cell-derived factor 1 (SDF1), insulin-like growth factor binding protein 6 (IGFBP6), sigma 1 receptor, regulators of G-protein signaling protein 4 (RGS4), Wnt1 responsive $\mathrm{Cdc} 42$ homolog (Wrch1), $\mathrm{Ca}^{2+} /$ calmodulin-dependent protein kinase II $\alpha$ subunit (CaMKII $\alpha)$, and $\beta$-actin. Primer sequences are listed in Table 1 as forward (F) and reverse primers (R), and they were checked in the GenBank database (Bainbridge Island, WA) to avoid possible sequence homologies with other sequences. Primer concentrations were optimized before use. PCR reactions contained $2.5 \mathrm{ng} / \mu \mathrm{l}$ of forward and reverse primers, $4 \mathrm{mM}$ $\mathrm{MgCl}_{2}$, and $1 \mu \mathrm{l} \mathrm{cDNA}$ from the $20 \mu \mathrm{RT}$ reactions in a total volume of $20 \mu \mathrm{l}$. Cycling conditions for detecting the D1 receptor, IGFBP6, sigma 1 receptor, CaMKII $\alpha$, and Wrch1 expression were $95^{\circ} \mathrm{C}$ for $150 \mathrm{~s}$, followed by 40 cycles at $95^{\circ} \mathrm{C}$ for $10 \mathrm{~s}, 58^{\circ} \mathrm{C}$ for $15 \mathrm{~s}$, and $72^{\circ} \mathrm{C}$ for $20 \mathrm{~s}$. Cycling conditions for SDF1 and $\beta$-actin were identical to the above except that the reaction time at $72^{\circ} \mathrm{C}$ was $30 \mathrm{~s}$. Relative starting mRNA template concentrations were calculated using the standard curve method and normalized against $\beta$-actin mRNA levels. The PCR products were resolved on $1.5 \%$ agarose gels to confirm the expected sizes of the products. We used a twoway ANOVA to compare the expression of various genes between wild-type and D1 receptor mutant mice, and between saline- and cocaine-treated mice within each genotype (Zhang et al, 2002).

\section{Protein Extracts Preparation}

Mice were decapitated and brains were removed after either acute or chronic cocaine or saline injections. The $\mathrm{CPu}$ and $\mathrm{NAc}$ tissues were isolated by gross dissection. For the $\mathrm{CPu}$, extracts were prepared from individual mouse brains. For the NAc, tissues from 2-3 mice were pooled during extract isolation. The samples were homogenized in a buffer containing $20 \mathrm{mM}$ HEPES, pH 7.9, $0.4 \mathrm{M} \mathrm{NaCl}, 20 \%$ glycerol, $5 \mathrm{mM} \mathrm{MgCl}, 0.5 \mathrm{mM}$ EDTA, $0.1 \mathrm{mM}$ EGTA, $1 \%$ NP- $40,5 \mathrm{mM}$ DTT, and protease inhibitor cocktail as described (Zhang et al, 2002). Homogenates were incubated on ice and centrifuged at $12000 \mathrm{~g}$ at $4^{\circ} \mathrm{C}$, and protein concentrations were determined by the Bradford method as described (Zhang et al, 2002). 
Table I Oligonucleotide Primers Used for Quantitative RT Real-Time PCR for the Indicated Genes

\begin{tabular}{|c|c|c|c|}
\hline Gene & Acc. no. & Sequence $5^{\prime}$ to $3^{\prime}$ & Position \\
\hline \multirow[t]{2}{*}{$\overline{\mathrm{SDFI}}$} & NM0I3655 & F: GCATCAGTGACGGTAAACCAG & 50 \\
\hline & & R: GGGTCAATGCACACTTGTCTG & 223 \\
\hline \multirow[t]{2}{*}{ IGFBP6 } & NM008344 & F: GCGGGGTCTACAGCCCTAAG & 214 \\
\hline & & R: CAGCAGAGGTCCGTGGATTC & 413 \\
\hline Sigma I receptor & NMOIIOI4 & F: ACGCCTCGCTGTCTGAGTAC & 290 \\
\hline RGS4 & & R: TCCGGCTTGTCTCCTCTCTG & 398 \\
\hline \multirow[t]{2}{*}{ Wrch I } & XMI2506I & F: CTTGGTGTCTGGGGAGGATC & 9 \\
\hline & & R: TCTGGGTAGCTGCTCACACG & 198 \\
\hline CaMKIl $\alpha$ & $\times 14836$ & F: GCAGGTGTGTGAAGGTGCTG & 83 \\
\hline
\end{tabular}

Acc. no. indicates GenBank accession numbers. F and $\mathrm{R}$ represent forward and reverse primers, respectively. The positions of the primers relative to the translational start sites of the cDNA are also indicated.

\section{Western Blotting}

Samples $(20 \mu \mathrm{g})$ from each treatment condition were resolved on SDS-PAGE and transferred onto PVDF membranes (Zhang et al, 2002). The membranes were blocked with $5 \%$ nonfat dry milk in $10 \mathrm{mM}$ PBS, and incubated in primary antibodies followed by horseradish peroxidase-conjugated secondary antibodies. Immunoreactive signals were visualized using enhanced chemiluminescence. For each protein analyzed, Western blots were repeated at least three times. We used primary antibodies against IGFBP6 (1:1000), RGS4 (1:1000), cyclin D2 (CD2, $1: 1000)$, and actin $(1: 3000)$ (Santa Cruz Biotechnology, Santa Cruz, CA). We also used c-Fos and $\Delta$ FosB as controls for the sensitivity of detecting protein expression (Zhang et al, 2002). Blocking peptides were used to verify the specificities of the antibodies.

We scanned in Western blot results for each sample from different mice. The relative band intensity is defined as densities subtracted by background for each signal and was quantified using Metamorph program as described (Zhang et al, 2002). Equal amounts of protein were used for expression comparisons of each individual protein at the 0 and $2 \mathrm{~h}$ time points. Thus, the expression level for each protein can be compared with one another at these time points. Equal amounts of protein were also used for the 7day time point. A two-way ANOVA was used to compare the expression of various genes between wild-type and D1 receptor mutant mice, and between saline- and cocainetreated mice within each genotype (Zhang et al, 2002).

\section{Immunohistochemistry}

We processed D1 receptor mutant and wild-type mice ( $n=6$ each) $24 \mathrm{~h}$ after the last chronic cocaine and saline injection as described (Zhang et al, 2002). Mice were anesthetized with Nembutal and transcardially perfused with PBS followed by $4 \%$ paraformaldehyde in PBS $(\mathrm{pH}$ 7.4). Brains were then fixed in $4 \%$ paraformaldehyde for $2 \mathrm{~h}$ and in $20 \%$ sucrose overnight (Zhang et al, 2002). Coronal sections were obtained on a cryostat at $25 \mu \mathrm{m}$. Free-floating sections were blocked with $0.4 \%$ Triton X-100 and $0.1 \%$ BSA in PBS for $1 \mathrm{~h}$ and were incubated with primary goat anti-IGFBP6 $(1: 100)$ and rat anti-CD2 $(1: 400)$ antibodies (Santa Cruz Biotechnology, Santa Cruz, CA), and a rabbit anti-leumorphin antibody $(1: 100$, Serotec, Oxford, UK) at $4{ }^{\circ} \mathrm{C}$ overnight. The brain sections were then incubated with biotin-conjugated secondary antibodies for $1 \mathrm{~h}$ at room temperature and were incubated in $A B C$ reagent for $30 \mathrm{~min}$ (Vector Laboratories Inc., Burlingame, CA). The sections were processed in DAB and Nickel solutions. The immunostaining images were analyzed using a Metamorph program. The optical density of each cell body above the background level was measured and an average density for each mouse was calculated. A two-way ANOVA was used to compare the expression levels as before. Although the antiRGS4 antibody detected a strong signal in Western blotting, it did not produce obvious immunostaining signals.

\section{Immunocolocalization}

For IGFBP6 and dynorphin, wild-type sections obtained for immunostaining were incubated with goat anti-IGFBP6 and rabbit anti-leumorphin antibodies either together or alone overnight. These sections were then incubated with Alexa Fluor 488-conjugated donkey anti-goat and Alexa Fluor 546-conjugated donkey anti-rabbit secondary antibodies. For CD2/dynorphin colocalization, after CD2 immunostaining with $\mathrm{DAB}$ using a rat anti-CD2 antibody, wild-type sections were incubated in $1 \% \mathrm{H}_{2} \mathrm{O}_{2}$ in $\mathrm{PBS}$ for $10 \mathrm{~min}$ and overnight with a rabbit anti-leumorphin antibody. The sections were then incubated with biotin-conjugated antirat and anti-rabbit secondary antibodies for $1 \mathrm{~h}$ at room temperature, and incubated for $30 \mathrm{~min}$ in $\mathrm{ABC}$ reagent, and 
in DAB-Nickel solution (Zhang et al, 2002). CPu and NAc immunostaining images of brain sections were captured by SpotCam.

\section{Promoter Sequence Comparisons}

DNA sequences from both Celera and GenBank were used for promoter sequence comparisons. Either TGAGTAA or TGA(C/G)TCA was used for the AP-1 binding site (Morgan and Curran, 1991; Cole et al, 1995; Logan et al, 1996), and TGACGTCA was used for the CREB binding site (Cole et al, 1995) to search for 10 kilobase pairs of sequences upstream of the transcription initiation sites of the genes.

\section{RESULTS}

A Total of 109 Genes are Differentially Expressed by at least 1.2-Fold in the CPu in D1 Receptor Mutant and Wild-Type Mice after Repeated Cocaine Administration

The goal of the current study is to gain insights into how the long-lasting behavioral effects of repeated cocaine administration correlate with underlying changes in gene expression through the DA D1 receptors. Repeated cocaine administration can induce persistent behavioral changes that may reflect drug-induced neuronal plasticity (Robinson and Berridge 1993; Kalivas et al, 1998; Vanderschuren and Kalivas, 2000), and the D1 receptor has been shown to be critical in mediating cocaine-induced long-lasting behavioral changes (Xu et al, 2000; Zhang et al, 2002).

We used the microarray method to identify chronic cocaine-induced gene expression differences in the two groups of mice $24 \mathrm{~h}$ after cocaine withdrawal. Statistical analysis of three independent hybridization experiments indicates that gene expression differences exist between cocaine-treated wild-type and D1 receptor mutant mice. Using a cutoff of at least a 1.2-fold difference in expression, we found that 109 genes exhibited, on the average, a significant difference in cocaine-induced expression $(p<0.05)$, and at the same time no difference in salineinduced expression $(p>0.05)$, between wild-type and D1 receptor mutant mice after 7 days of injections (Supplemental Table 1). These genes were either down- or upregulated in the $\mathrm{CPu}$ in $\mathrm{D} 1$ receptor mutant mice compared to that in wild-type mice by repeated cocaine exposure. Based on GeneOntology annotations and an extensive literature analysis, we found that these genes encode a wide range of molecules that can be organized into different functional groups, including extracellular factors, channels, membrane receptors and modulators, intracellular signaling molecules, gene expression modulators, structural proteins, and those with yet unidentified functions (Figure 1 and Supplemental Table 1). There were also 395 genes that exhibited at least a 1.2-fold differential expression after 7 days of saline treatment in wild-type and D1 receptor mutant mice, such as that encoding prodynorphin (Xu et al, 1994a; Moratalla et al, 1996; Supplemental Table 2). Whereas baseline expression difference of some genes between the D1 receptor mutant and wild-type mice may contribute to cocaine-induced differences, changes in many other genes may reflect compensatory changes produced by the D1 receptor gene mutation.

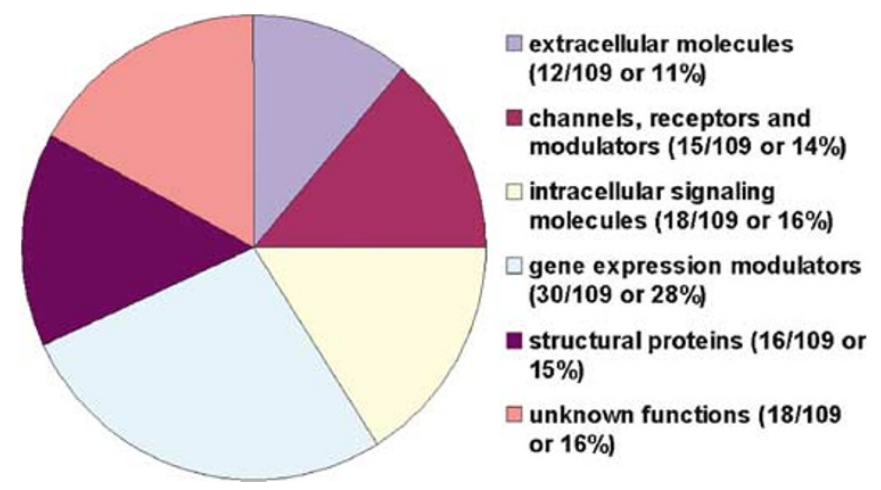

Figure I A total of 109 genes are differentially down- or upregulated by at least I.2-fold in the CPu in DI receptor mutant mice compared to wildtype mice by repeated cocaine administration. DI receptor mutant and wild-type mice ( $n=12$ each) were treated with $20 \mathrm{mg} / \mathrm{kg}$ of cocaine or saline for 7 consecutive days, and differences in gene expression in the CPu were compared using microarray genechips. Based on two-way ANOVA statistical and functional analyses, the differentially expressed genes were grouped into those encoding extracellular molecules, channels, receptors and modulators, intracellular signaling molecules, gene expression modulators, structural proteins, and proteins with unknown function.

\section{Verifying Cocaine-Induced Gene Expression Difference by Quantitative RT Real-Time PCR}

We are particularly interested in identifying chronic cocaine-induced long-lasting neuroplastic changes in the brain and selected two genes each from the extracellular factor, channel, membrane receptor and modulator as well as intracellular signaling molecule functional groups and used quantitative RT real-time PCR to verify their differential expression in the $\mathrm{CPu}$ in $\mathrm{D} 1$ receptor mutant and wild-type mice $24 \mathrm{~h}$ after cocaine withdrawal. These genes encode SDF1, IGFBP6, the sigma 1 receptor, RGS4, Wrch1, and CaMKII $\alpha$. SDF1 belongs to the CXC family of chemokines that are chemoattractant molecules (Baggiolini, 1998). Both SDF1 and its receptor, CXCR4, are expressed in the brain and are important for neuronal cell migration (Ma et al, 1998). IGFs are growth regulators of neurons and astrocytes, and IGFBPs are a family of at least six extracellular proteins that bind to IGFs with high affinities (Murphy, 1998; Zumkeller and Westphal, 2001). IGFBP6 binds IGF-II with high affinity and may inhibit IGF-II actions and both IGFBP6 and IGF-II are expressed in the central nervous system (Murphy, 1998; Zumkeller and Westphal, 2001). The sigma 1 receptor is associated with both plasma and intracellular membranes and is expressed in the $\mathrm{CPu}, \mathrm{NAc}$, and amygdala in the brain (Matsumoto et al, 2002; Romieu et al, 2003). This receptor can modulate cocaine-induced behaviors (Matsumoto et al, 2002; Romieu et al, 2003). RGS proteins are a family of diverse and multifunctional signaling proteins that modulate G-protein functions (Zhong and Neubig, 2001; Hollinger and Hepler, 2002). RGS4 is exclusively expressed in the brain (Zhong and Neubig, 2001; Hollinger and Hepler, 2002). Wrch1 is a homolog of the Rho family of GTPase that also shares $57 \%$ amino-acid sequence homology with Cdc42 (Tao et al, 2001). Wrch1 is expressed in the brain and its expression is increased in response to Wnt signaling, which plays important roles in cell proliferation and adhesion (Tao et al, 2001). CaMKII is a kinase with a broad spectrum of 
substrates that coordinates a variety of neuronal functions such as gene expression, membrane excitability, and neuronal transmission (Lisman et al, 2002). Multiple isoforms of CaMKII exist and the $\alpha$ isoform is abundantly expressed in forebrain neurons (Lisman et al, 2002). Together, changes in the expression of these molecules can change the responsiveness of the D1 receptor-expressing neurons to further neuronal stimulation.

As identified by the Affymetrix genechips, SDF1, IGFBP6, the sigma 1 receptor, RGS4, and CaMKII $\alpha$ were all induced in the $\mathrm{CPu}$ in wild-type mice, and Wrch1 was induced in the $\mathrm{CPu}$ in $\mathrm{D} 1$ receptor mutant mice after repeated cocaine injections (Figure 2). Moreover, these genes were differentially expressed in the $\mathrm{CPu}$ of the two groups of mice after repeated cocaine injections (Figure 2). Importantly, the expression of these genes in the $\mathrm{CPu}$ was not different in saline- or acute cocaine-treated D1 receptor mutant and wild-type mice (Figure 2), suggesting the involvement of these molecules in chronic cocaine-induced neuroadaptations. As a control, we found that the D1 receptor is differentially expressed in the wild-type and D1 receptor mutant mice (Figure 2).

\section{Verifying Cocaine-Induced Gene Expression Difference by Western Blotting and Immunostaining}

We next selected IGFBP6 in the extracellular factor group, RGS4 in the channel, membrane receptor and modulator group, and CD2 in the intracellular signaling molecule group and examined their differential expression in the $\mathrm{CPu}$ and NAc in D1 receptor mutant and wild-type mice at the protein level. Our microarray studies indicate that, while it is not induced in the $\mathrm{CPu}$ in wild-type mice (data not shown), CD2 expression is reduced in the $\mathrm{CPu}$ in $\mathrm{D} 1$ receptor mutant mice after repeated exposure to cocaine (Supplemental Table 1). CD2 is an essential mediator for the progression through the G1 phase of the cell cycle (Coqueret, 2002). CD2 may also have a role in maintaining neural cell proliferation and differentiation (Huard et al, 1999).

Western blot analyses indicated that IGFBP6 and RGS4 expression is increased in the $\mathrm{CPu}$ in wild-type mice after repeated cocaine injections (Figure 3a). Moreover, all three genes showed attenuated expression in the $\mathrm{CPu}$ in $\mathrm{D} 1$ receptor mutant mice upon repeated exposure to cocaine compared to that in saline-treated mutant mice and that in wild-type mice (Figure 3a). Repeated cocaine injections induced RGS4 expression in the NAc in wild-type mice but not in D1 receptor mutant mice (Figure $3 \mathrm{~b}$ ). Chronic cocaine injections also attenuated CD2 expression in the D1 receptor mutant mice compared to that in wild-type mice (Figure 3b). There was no difference in the expression of these genes in the $\mathrm{CPu}$ or NAc in the two groups of mice either after saline or acute cocaine injections (Figure $3 \mathrm{a}$ and b). These results suggest that repeated cocaine administration influences the expression of these genes via the D1 receptor.

To further confirm the above findings, we performed immunostaining experiments. Quantitative analysis indicates that, consistent with the Western blot results, the expression of IGFBP6 and CD2 is lower in the CPu in D1 receptor mutant mice than in wild-type mice after repeated
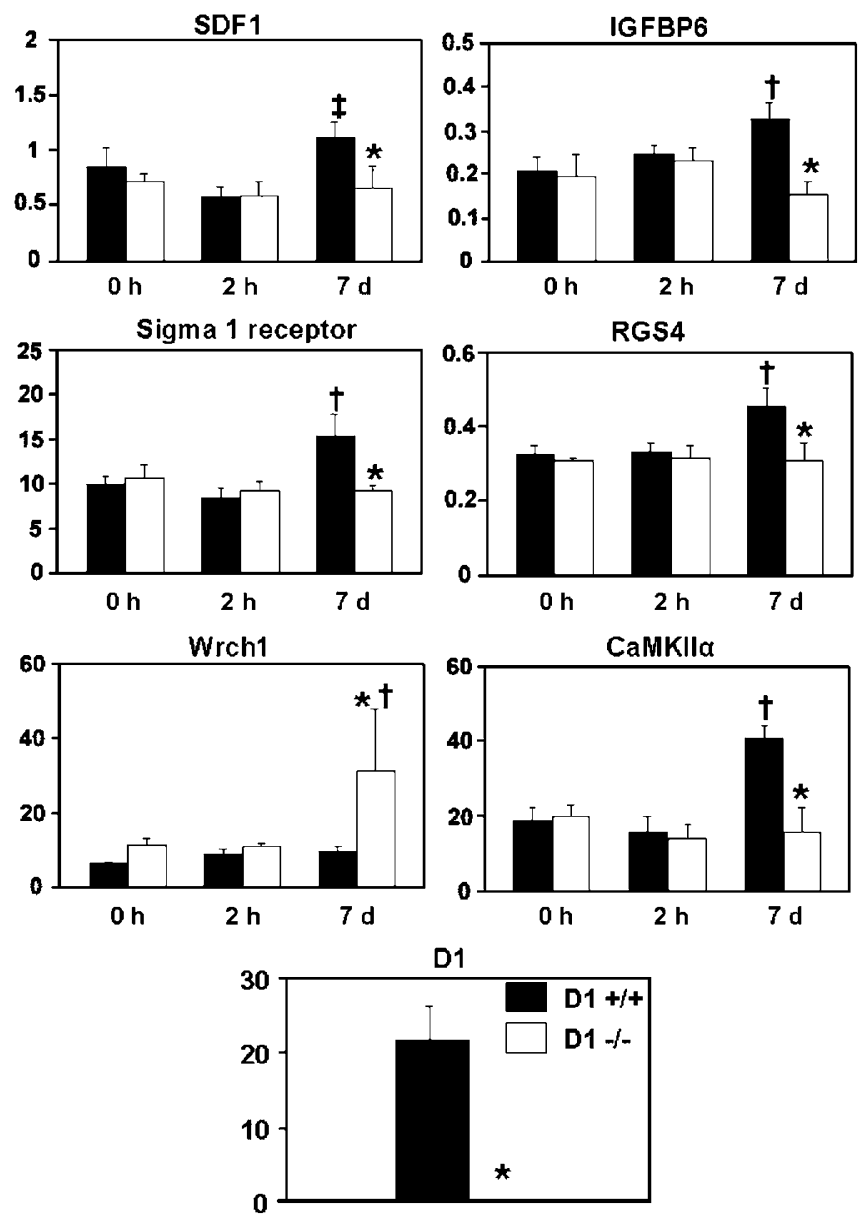

Figure 2 Differential gene expression in the CPu in DI receptor mutant and wild-type mice after repeated exposure to cocaine. DI receptor mutant and wild-type mice ( $n=4$ mice at each time point) were treated either with an acute $30 \mathrm{mg} / \mathrm{kg}$ dose of cocaine or saline, or with $20 \mathrm{mg} / \mathrm{kg}$ of cocaine or saline ( $0 \mathrm{~h}$ control) for 7 consecutive days. RNA was isolated from individual brains and quantitative RT real-time PCR was performed. $Y$-axes represent relative expression levels. ${ }^{*} p<0.05$ and $p<0.05$ between and within groups, respectively. $0.05<p<0$. I within group. The DI receptor gene was used as a control.

cocaine injections (Figure $4 \mathrm{a}-\mathrm{d}$ and g). Moreover, whereas dynorphin expression is similar to previous reports (Xu et al, 1994a; Moratalla et al, 1996; Drago et al, 1996), cocaine-induced dynorphin expression is reduced in the $\mathrm{CPu}$ in $\mathrm{D} 1$ receptor mutant mice (Figure $4 \mathrm{e}-\mathrm{g}$ ).

Pretreatment of the D1 Receptor Antagonist SCH23390 Attenuates the Induction of IGFBP6, RGS4, and CD2 in the CPu by Repeated Cocaine Administration

Since both basal and acute cocaine-induced expressions of IGFBP6, RGS4, and CD2 are not different in the CPu and NAc of D1 receptor mutant and wild-type mice, our results suggest that the induction of these genes by repeated cocaine administration depends on a functional D1 receptor, and that these findings are unlikely to be related to developmental compensations of the D1 receptor gene mutation. To further confirm this notion, we pretreated wild-type mice with the D1 receptor antagonist SCH23390 and then compared IGFBP6, RGS4, and CD2 induction in 
a

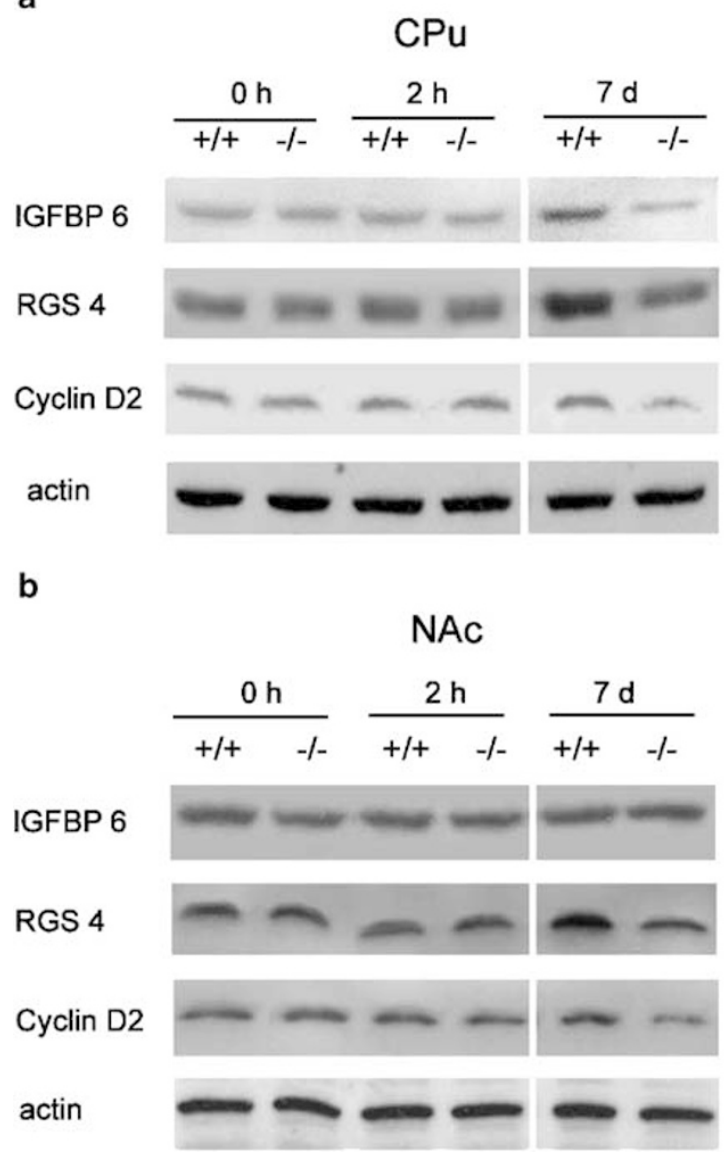

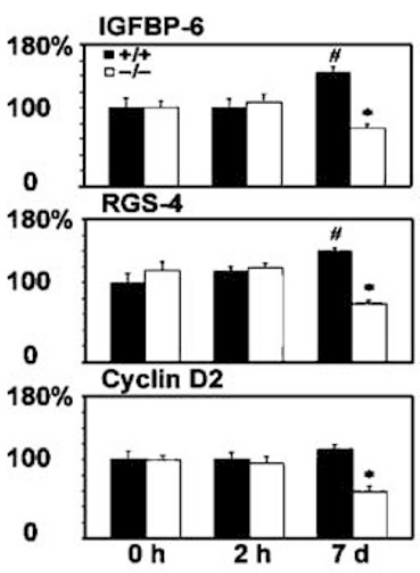
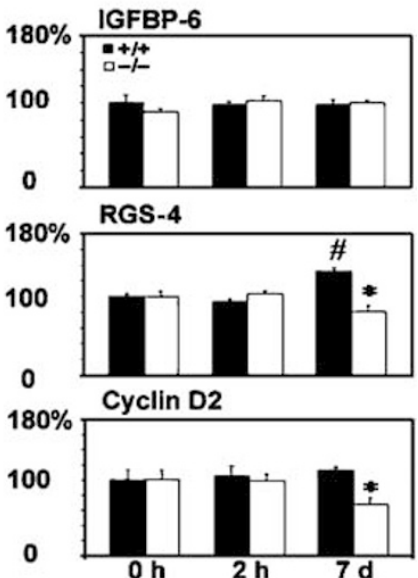

Figure 3 Differential gene expression in DI receptor mutant mice and wild-type mice after repeated cocaine administration. Western blotting for IGFBP6, RGS4, and CD2 using extracts prepared from the CPu ((a) $n=4$ mice at each time point) and NAc ((b) $n=8-12$ mice with 4-7 males and 4-5 females at each time point) of individual wild-type $(+/+)$ and $\mathrm{DI}$ receptor mutant $(-/-)$ mice after an acute cocaine injection at the $30 \mathrm{mg} / \mathrm{kg}$ dose $(2 \mathrm{~h})$ or 7 days $(7 \mathrm{~d})$ of cocaine or saline $(0 \mathrm{~h})$ treatment. Equal amounts of protein were loaded in each lane. We repeated each Western blot experiment for at least three times, and individual mouse gave parallel gene expression changes within each group. Mean + SEM of expression levels with saline-treated wild type as $100 \%$ controls. ${ }^{*} p<0.05$ and ${ }_{p}^{\#}<0.05$ between and within groups, respectively.

the $\mathrm{CPu}$ by chronic cocaine administration. As shown in Figure 5, SCH23390 treatment before cocaine injections blocked cocaine-induced IGFPB6 and RGS4 expression and attenuated CD2 expression, while SCH23390 itself had no effects on the expression of these genes. These results are parallel to those obtained using the D1 receptor mutant mice.

\section{IGFBP6 and CD2 are Produced in Dynorphin-Positive Neurons}

Repeated cocaine injections can induce target gene expression via the D1 receptors either directly in D1 receptorexpressing neurons, or indirectly in adjacent neurons via interactions with the D1 receptor-expressing neurons. To understand whether the attenuated IGFBP6 and CD2 expression can be at least partially attributed to a reduced expression in D1 receptor-expressing neurons following repeated cocaine injections, we performed colocalization experiments. We previously found that dynorphin expression is dependent on the $\mathrm{D} 1$ receptor (Xu et al, 1994a; Moratalla et al, 1996; Drago et al, 1996) and thus used dynorphin as a marker for D1 receptor-expressing neurons. As shown in Figure 6, most of IGFBP6- and CD2-positive neurons also expressed dynorphin in the $\mathrm{CPu}$, suggesting that a lack of D1 receptor led to a reduced expression of these two proteins in D1 receptor-expressing neurons after repeated cocaine injections.

\section{Many of the Differentially Expressed Genes Contain AP-1 Binding Sites in Their Promoter Regions}

Activation of the $\mathrm{D} 1$ receptor by cocaine leads to activation of the transcription factors c-Fos, $\triangle F o s B$, and CREB (Graybiel et al, 1990; Moratalla et al, 1996; Carlezon et al, 1998; Kelz et al, 1999; Nestler et al, 1999; Nestler, 2000; Zhang et al, 2002; Colby et al, 2003). These observations suggest that AP-1 transcription complexes and CREB may participate in the regulation of target genes upon repeated exposure to cocaine. To gain insights into how the differentially expressed genes are regulated in the D1 receptor-expressing neurons following repeated cocaine administration, we analyzed the promoter regions of the genes whose differential expression through the D1 receptors has been verified by the above methods. We found that all of these genes contain AP-1 binding sites in their promoter regions (Figure 7). Two genes also contain the CREB binding sites (Figure 7). These results suggest that 

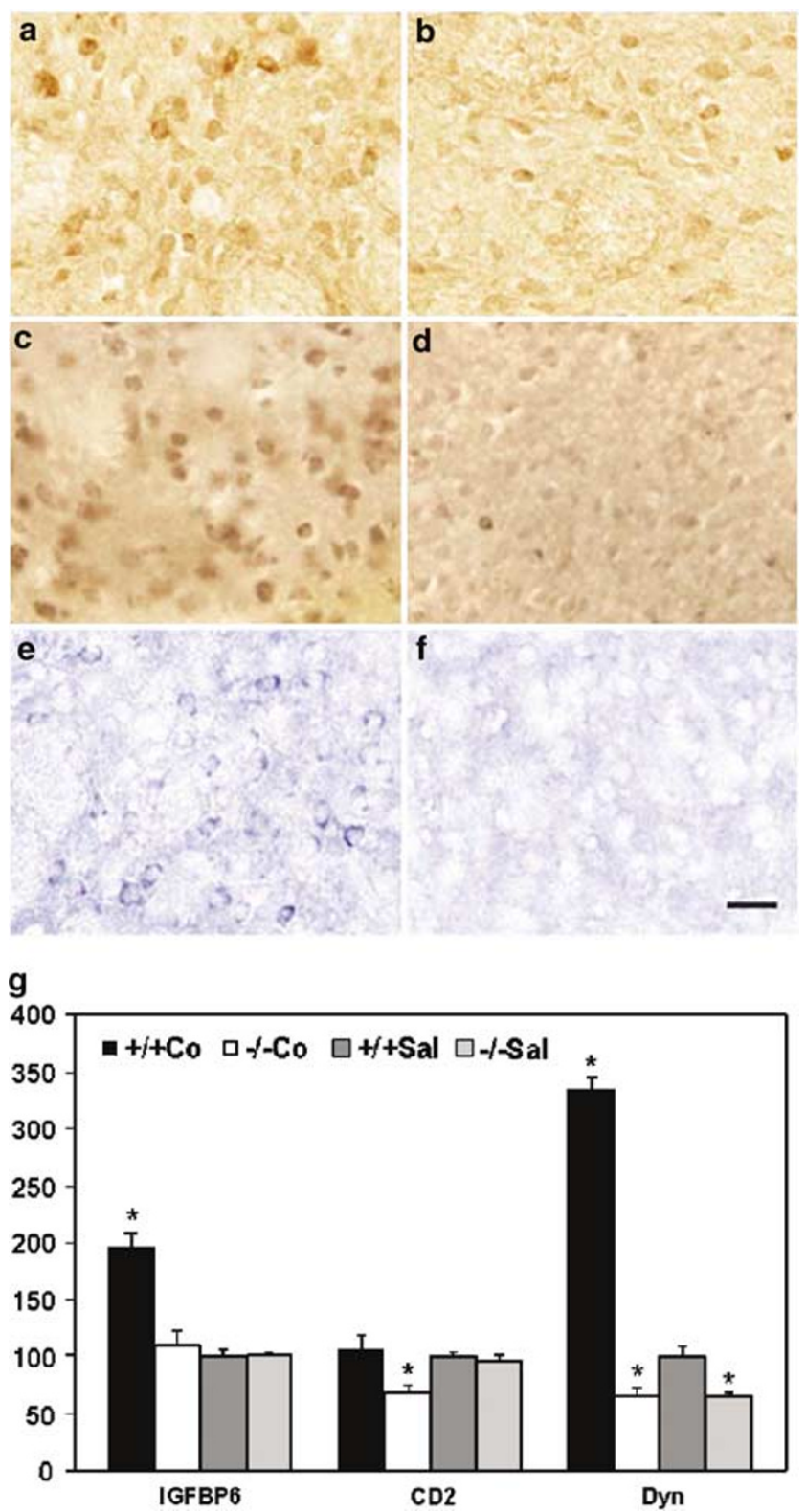

Figure 4 Differential IGFBP6 and CD2 expression in the CPu of DI receptor mutant mice and wild-type mice after repeated cocaine administration. DI receptor mutant and wild-type mice ( $n=6$ each) were treated with cocaine or saline twice daily for 7 consecutive days. Coronal sections ( $n=4$ for each mouse) through the CPu of wild-type (a, c, e) and DI receptor mutant $(b, d, f)$ mice were stained with antibodies that recognize IGFBP6 (a, b), CD2 (c, d), and dynorphin (e, f). The scale bar is $50 \mu \mathrm{m}$. (g) Quantification of IGFBP6, CD2, and dynorphin expression under different conditions. $* 0<0.05$ between groups.

these genes are potential candidates that are regulated by either AP-1 or CREB or both in D1 receptor-expressing neurons following repeated exposure to cocaine.

\section{DISCUSSION}

We previously investigated acute cocaine-induced IEG expression and MAPK activation via the D1 receptors

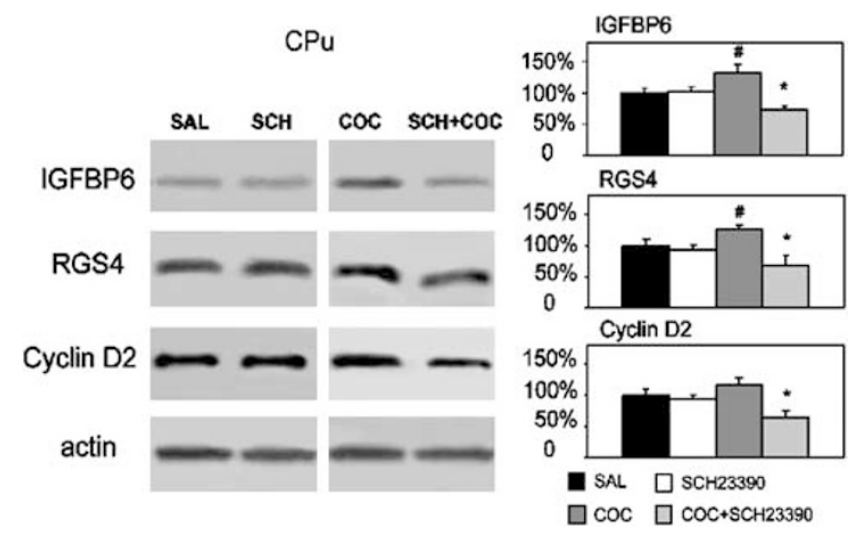

Figure 5 The DI receptor antagonist $\mathrm{SCH} 23390$ can block IGFBP6, RGS4, and CD2 expression in the CPu induced by repeated cocaine administration. Wild-type mice ( $n=4$ for each condition) were treated with $\mathrm{SCH} 23390$ or saline 30 min before cocaine or saline injections twice daily for 7 consecutive days. Left: Equal amounts of protein were loaded in each lane for Western blotting. Right: Mean + SEM of expression levels with saline-treated wild type as 100\% controls. We repeated the experiment for at least six times using different mice, and all mice in each group gave similar results. SCH, SCH23390; COC, cocaine; SAL, saline. ${ }^{*} p<0.05$ compared with the saline + cocaine group. ${ }^{\#} p<0.05$ compared with the saline + saline and saline $+\mathrm{SCH} 23390$ groups.

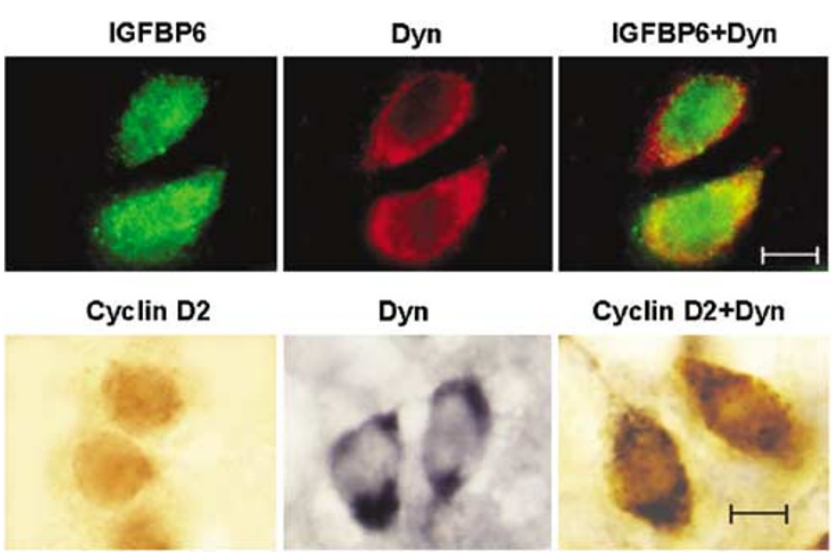

Figure 6 IGFBP6 and CD2 are coexpressed in dynorphin-positive neurons in the $\mathrm{CPu}$. Wild-type mice $(n=6$ each) were treated with cocaine or saline twice daily for 7 consecutive days. Coronal sections $(n=4$ for each mouse) through the CPu of the mice were stained with antibodies that recognize IGFBP6, CD2, or dynorphin or in combination. The scale bar is $5 \mu \mathrm{m}$.

(Zhang et al, 2002, 2004). We have now used D1 receptor mutant mice that exhibit attenuated cocaine-induced behaviors compared to wild-type mice and microarrays to identify chronic cocaine-induced genes whose expression depends on a functional D1 receptor $24 \mathrm{~h}$ after cocaine withdrawal. We found that, whereas their expression is not different after saline injections, 109 genes are either up- or downregulated by at least 1.2 -fold in the $\mathrm{CPu} \mathrm{D} 1$ receptor mutant mice compared to wild-type mice by repeated cocaine injections. These genes can be classified into several functional groups. We selected six candidate genes from three functional groups and verified their differential expression in the $\mathrm{CPu}$ of cocaine- and saline-treated $\mathrm{D} 1$ 


\section{AP-1 binding site TGAGTAA or TGA(C/G)TCA}

CREB binding site TGACGTCA

\begin{tabular}{|c|c|c|}
\hline IGFBP6 & $5^{\prime} \ldots$ ACATGGTGACTCATAAACA ... & \\
\hline SDF1 & 5 '... GCTATCTGACTCAGGTTT ... & \\
\hline RGS4 & $5^{\prime}$... GAACCATGACTCAATGCAT ... & \\
\hline Sigma 1 receptor & $5^{\prime}, . .$. CCTCCATGAGTCACTCAAA ... & \\
\hline Wrch1 & 5 '... ACCTAGTGACTC AGCTTAT ... & \\
\hline CaMKIla & $5, \ldots$ GAAGTATGAGTAATATTTG ... & 5 '... CGCTAATGACGTCAGCCCCC ... \\
\hline Cyclin D2 & 5 '... AAATTTTGAGTAATTGCTTT ... & 5'... TGTGGGTGACGTCAAAATTC ... \\
\hline
\end{tabular}

Figure 7 Promoter sequence comparisons of the differentially expressed genes. Promoter sequences were obtained from either Celera or GenBank. TGAGTAA and TGA(C/G)TCA were used for the AP-I site, and TGACGTCA was used for the CRE site to search for sequences upstream of the transcription initiation sites of the candidate genes.

receptor mutant and wild-type mice by performing quantitative RT real-time PCR. Because the expression level and cellular location of the proteins of the candidate genes may be different from those of the mRNA, we selected one candidate molecule each from the same three functional groups and performed Western blotting and immunostaining using brains from cocaine- and saline-treated D1 receptor mutant and wild-type mice. We also verified the dependency of their expression on the D1 receptor after cocaine treatment using a D1 receptor antagonist. We found that genes encoding extracellular factors, receptors and modulators, and intracellular signaling molecules can be regulated by chronic cocaine treatment via the $\mathrm{D} 1$ receptors. Moreover, these genes all contain AP-1 binding sites in their promoter regions, making them potential targets for AP-1 regulation following repeated cocaine administration.

\section{Extracellular Molecules}

We found that the expression of IGFBP6 and SDF1 is induced in the $\mathrm{CPu}$ in wild-type mice and it is attenuated in the $\mathrm{CPu}$ in $\mathrm{D} 1$ receptor mutant mice following repeated cocaine injections. These results suggest that IGFBP6 and SDF1 can be induced by repeated cocaine administration in the $\mathrm{CPu}$ in mice, and that the induction is at least partially dependent on a functional D1 receptor. IGFs promote the proliferation of neurons and astrocytes (Murphy, 1998; Zumkeller and Westphal, 2001). IGFBP6 binds to IGF-II with high affinity and may inhibit IGF-II actions (Murphy, 1998; Zumkeller and Westphal, 2001). SDF1 affects neuronal cell migration through its receptor CXCR4 (Ma et al, 1998). Chronic cocaine administration leads to increased dendritic branching and dendritic spine density on the medium spine neurons and the prefrontal cortex pyramidal neurons (Robinson and Kolb, 1999). These dendritic morphological changes may contribute to cocaine-induced neuroadaptations. Although definitive evidence is still lacking, it is possible that IGFBP6 and SDF1 may influence chronic cocaine-induced increases in dendritic reorganization in medium spiny neurons by regulating local neuronal proliferation and migration. The significance of differential regulation of IGFBP6 in the $\mathrm{CPu}$ and NAc by chronic cocaine administration is not yet known.

\section{Receptors and Modulators}

We found that the expression of sigma 1 receptor and RGS4 in the D1 receptor mutant mice, unlike that in the wild-type mice, is not upregulated following repeated cocaine administration, suggesting the importance of the D1 receptor in the induction of these genes. The sigma 1 receptor is involved in modulating the rewarding effects of cocaine (Romieu et al, 2003). Antagonists for this receptor block the acute locomotor stimulating effect of cocaine and attenuate cocaine-induced behavioral sensitization (Ujike et al, 1996; Matsumoto et al, 2002). The sigma 1 receptor may also modulate dopaminergic neurotransmission by modulating DA release (Ault and Werling, 1999). Changes in the expression of the sigma 1 receptor can thus change the behavioral responses to cocaine by exerting both preand postsynaptic influences. RGS4 proteins can modulate G-protein-coupled receptor function in the brain (Zhong and Neubig, 2001; Hollinger and Hepler, 2002). Selective pharmacological stimulation of the DA D1 and D2 receptors has been shown to decrease and increase RGS4 expression in the striatum, respectively (Geurts et al, 2002; Taymans et al, 2003). Changes in RGS4 expression might thus be involved in alterations of signal transduction occurring after activation of D1 receptors by repeated cocaine stimulation.

\section{Intracellular Signaling Molecules}

We also found that Wrchl is upregulated by repeated cocaine injections in the $\mathrm{CPu}$ in $\mathrm{D} 1$ receptor mutant mice but not wild-type mice. We speculate that Wrch1 may inhibit cocaine-induced and D1 receptor-mediated behavioral changes. We previously found that $\beta$-catenin, which is a key member in the Wnt signaling pathway, was induced by acute cocaine administration in the NAc and by repeated cocaine treatment in both the NAc and $\mathrm{CPu}$ in wild-type mice (Zhang et al, 2002). On the contrary, acute cocaine administration reduced $\beta$-catenin expression in the $\mathrm{CPu}$ and chronic cocaine injections decreased $\beta$-catenin 
expression in the NAc in D1 receptor mutant mice (Zhang et al, 2002). Changes in the Wnt signaling pathway can influence Wrch1 function and neuronal cell proliferation and cell adhesion and thus contribute to chronic cocaineinduced neuroadaptations.

We found that, unlike that in the $\mathrm{CPu}$ in wild-type mice, CaMKII $\alpha$ is not upregulated in D1 receptor mutant mice after chronic cocaine treatment. CaMKII is activated in response to increases in intracellular calcium levels and it can modulate synaptic plasticity both pre- and postsynaptically (Lisman et al, 2002). In the postsynaptic density, CaMKII can directly interact with and phosphorylate many proteins, including the $N$-methyl-D-aspartate receptor $2 \mathrm{~B}$ subunit and $\alpha$-amino-3-hydroxy-5-methyl-4-isoxazole propionic acid receptor 1 , both of which mediate excitatory neurotransmission (Yoshimura et al, 2000; Lisman et al, 2002). The D1 receptor-dependent change in CaMKII $\alpha$ expression following repeated cocaine injections can thus change neurotransmission in the striatum.

Finally, we found that CD2 expression is downregulated in the $\mathrm{CPu}$ in $\mathrm{D} 1$ receptor mutant mice but not in wild-type mice after repeated cocaine injections. CD2 is a mediator for the progression through the G1 phase of the cell cycle (Coqueret, 2002). In the central nervous system, CD2 has also been shown to be required for both the proliferation of the granule cell precursors and the proper differentiation of granule and stellate interneurons in the cerebellum (Huard et al, 1999). It is possible that continuous CD2 expression during repeated cocaine injections is necessary for the maintenance of dendritic morphology or for the local proliferation of neuronal cells in the NAc and $\mathrm{CPu}$.

\section{AP-1-Regulated Genes in D1 Receptor-Expressing Neurons may Contribute to Cocaine-Induced Neuroadaptations}

We found that the D1 receptor antagonist SCH23390 blocked cocaine-induced changes in IGFBP6, RGS4, and $\mathrm{CD} 2$ expression in the $\mathrm{CPu}$ while it did not affect the expression of these genes. These results are completely parallel to those obtained using the D1 receptor mutant mice, and they argue that these gene expression changes are indeed induced by chronic cocaine administration via the D1 receptor and are not due to compensatory effects produced from the $\mathrm{D} 1$ receptor gene mutation.

Analyses of the promoter sequences of the above candidate genes showed that they all contain AP-1 binding sites. Two genes also contain the CREB binding sites in the promoters. These results and the fact that IGFBP6 and CD2 can be induced in dynorphin-positive neurons in the $\mathrm{CPu}$ by cocaine support a molecular model in which different classes of genes can serve as potential targets for regulation by either AP-1 transcription complexes or CREB or both in D1 receptor-expressing neurons following repeated cocaine injections. These changes in gene expression may contribute to cocaine-induced persistent neurochemical and behavioral changes (Zhang et al, 2004).

Our current study focused on confirming genes whose expression changes correlate with chronic cocaine-induced behavioral changes, and whose expression in the $\mathrm{CPu}$ and NAc depends on a functional D1 receptor. A more detailed bioinformatics analysis of the results in the future may uncover more functionally related changes in gene expression following repeated cocaine injections. Moreover, the gene expression changes identified in our study involve a relatively short $24 \mathrm{~h}$ cocaine withdrawal time window, and how these changes relate to the persistent nature of drug addiction remains to be determined. To truly identify genes that are physiologically relevant to chronic cocaine-induced neuroadaptations, we will need to functionally perturb the expression of the candidate genes in vivo and investigate whether and how they affect behavioral changes in response to chronic cocaine administration. Whether these candidate genes are regulated by $\mathrm{AP}-1$ transcription complexes in response to repeated cocaine administration also needs further investigation. We used both male and female mice in the current study, and potential sex-related gene expression differences following cocaine administration need to be addressed. It should also be noted that posttranslational modifications, such as protein phosphorylation, are an integral part of molecular responses to repeated exposure to cocaine (Greengard et al, 1999). The proteomics method will address this possibility (Husi and Grant, 2001). The combined use of gene-targeted mice that exhibit altered responses to cocaine, with microarrays and proteomics, and proper physiological testing of the putative target genes may provide novel insights into the molecular basis of the persistence of drug dependence.

\section{ACKNOWLEDGEMENTS}

We thank Bruce Aronow and Sarah Williams at the Bioinformatics Core for advice on the analysis of the microarray results, and the Microarray Core at the Children's Hospital Research Foundation at Cincinnati for microarray hybridization and data scanning. JZ is supported by NIDA (DA11284). MX is supported by NIDA (DA11005 and DA13786).

\section{REFERENCES}

Albertson DN, Pruetz B, Schmidt CJ, Kuhn DM, Kapatos G, Bannon MJ (2004). Gene expression profile of the nucleus accumbens of human cocaine abusers: evidence for dysregulation of myelin. J Neurochem 88: 1211-1219.

Anderson SM, Bari AA, Pierce RC (2003). Administration of the D1-like dopamine receptor antagonist $\mathrm{SCH}-23390$ into the medial nucleus accumbens shell attenuates cocaine priminginduced reinstatement of drug-seeking behavior in rats. Psychopharmacology 168: 132-138.

Ault DT, Werling LL (1999). Phencyclidine and dizocilpine modulate dopamine release from rat nucleus accumbens via sigma receptors. Eur J Pharmacol 386: 145-153.

Baggiolini M (1998). Chemokines and leukocyte traffic. Nature 392: $565-568$.

Baker DA, Fuchs RA, Specio SE, Khroyan TV, Neisewander JL (1998). Effects of intraaccumbens administration of SCH-23390 on cocaine-induced locomotion and conditioned place preference. Synapse 30: 181-193.

Berke JD, Hyman SE (2000). Addiction, dopamine, and the molecular mechanisms of memory. Neuron 25: 515-532.

Berke JD, Paletzki RF, Aronson GJ, Hyman SE, Gerfen CR (1998). A complex program of striatal gene expression induced by dopaminergic stimulation. J Neurosci 18: 5301-5310. 
Bibb JA, Chen J, Taylor JR, Svenningsson P, Nishi A, Snyder GL et al (2001). Effects of chronic exposure to cocaine are regulated by the neuronal protein Cdk5. Nature 410: 376-380.

Cabib S, Castellano C, Cestari V, Filibeck U, Puglisi-Allegra S (1991). D1 and D2 receptor antagonists differently affect cocaine-induced locomotor hyperactivity in the mouse. Psychopharmacology 105: 335-339.

Caine SB, Koob GF (1994). Effects of dopamine D-1 and D-2 antagonists on cocaine self-administration under different schedules of reinforcement in the rat. J Phar Exp Ther 270: 209-218.

Caine SB, Negus SS, Mello NK (2000). Effects of dopamine D1-like and D2-like agonists on cocaine self-administration in rhesus monkeys: rapid assessment of cocaine dose-effect functions. Psychopharmacology 148: 41-51.

Caine SB, Negus SS, Mello NK, Bergman J (1999). Effects of dopamine D1-like and D2-like agonists in rats that selfadminister cocaine. J Phar Exp Ther 291: 353-360.

Carlezon Jr WA, Thome J, Olson VG, Lane-Ladd SB, Brodkin ES, Hiroi $\mathrm{N}$ et al (1998). Regulation of cocaine reward by CREB. Science 282: 2272-2275.

Cervo L, Samanin R (1995). Effects of dopaminergic and glutamatergic receptor antagonists on the acquisition and expression of cocaine conditioning place preference. Brain Res 673: $242-250$.

Civelli O, Bunzow JR, Grandy DK (1993). Molecular diversity of the dopamine receptors. Annu Rev Pharmacol Toxicol 32: 281-307.

Colby CR, Whisler K, Steffen C, Nestler EJ, Self DW (2003). Striatal cell type-specific overexpression of DeltaFosB enhances incentive for cocaine. J Neurosci 23: 2488-2493.

Cole RL, Konradi C, Douglass J, Hyman SE (1995). Neuronal adaptation to amphetamine and dopamine: molecular mechanisms of prodynorphin gene regulation in rat striatum. Neuron 14: 813-823.

Coqueret O (2002). Linking cyclins to transcriptional control. Gene 299: 35-55.

Drago J, Gerfen CR, Westphal H, Steiner H (1996). D1 dopamine receptor-deficient mouse: cocaine-induced regulation of immediate-early gene and substance $\mathrm{P}$ expression in the striatum. Neuroscience 74: 813-823.

Everitt BJ, Wolf ME (2002). Psychomotor stimulant addiction: a neural systems perspective. J Neurosci 22: 3312-3320.

Freeman WM, Brebner K, Lynch WJ, Robertson DJ, Roberts DC, Vrana KE (2001a). Cocaine-responsive gene expression changes in rat hippocampus. Neuroscience 108: $371-380$.

Freeman WM, Nader MA, Nader SH, Robertson DJ, Gioia L, Mitchell SM et al (2001b). Chronic cocaine-mediated changes in non-human primate nucleus accumbens gene expression. J Neurochem 77: 542-549.

Geurts M, Hermans E, Maloteaux J (2002). Opposite modulation of regulators of G protein signalling-2 RGS2 and RGS4 expression by dopamine receptors in the rat striatum. Neurosci Lett 333: $146-150$

Gingrich JA, Caron MG (1993). Recent advances in the molecular biology of dopamine receptors. Annu Rev Neurosci 16: 299-321.

Graybiel AM, Moratalla R, Robertson HA (1990). Amphetamine and cocaine induce drug-specific activation of the $c$-fos gene in striosome-matrix compartments and limbic subdivisions of the striatum. Proc Natl Acad Sci USA 87: 6912-6916.

Grech DM, Spealman RD, Bergman J (1996). Self-administration of D1 receptor agonists by squirrel monkeys. Psychopharmacology 125: $97-104$.

Greengard P, Allen PB, Nairn AC (1999). Beyond the dopamine receptor: the DARPP-32/protein phosphatase-1 cascade. Neuron 23: 435-447.

Henry DJ, White FJ (1995). The persistence of behavioral sensitization to cocaine parallels enhanced inhibition of nucleus accumbens neurons. J Neurosci 15: 6287-6299.
Hollinger S, Hepler JR (2002). Cellular regulation of RGS proteins: modulators and integrators of $\mathrm{G}$ protein signaling. Pharmacol Rev 54: 527-559.

Huard JM, Forster CC, Carter ML, Sicinski P, Ross ME (1999). Cerebellar histogenesis is disturbed in mice lacking cyclin D2. Development 126: 1927-1935.

Husi H, Grant SG (2001). Proteomics of the nervous system. Trends Neurosci 24: 259-266.

Hyman SE, Malenka RC (2001). Addiction and the brain: the neurobiology of compulsion and its persistence. Nat Rev Neurosci 2: 695-703.

Kalivas PW, Pierce RC, Cornish J, Sorg BA (1998). A role for sensitization in craving and relapse in cocaine addiction. J Psychopharmacol 12: 49-53.

Katz JL, Kopajtic TA, Myers KA, Mitkus RJ, Chider M (1999). Behavioral effects of cocaine: interactions with D1 dopaminergic antagonists and agonists in mice and squirrel monkeys. J Phar Exp Ther 291: 265-279.

Kelley AE, Berridge KC (2002). The neuroscience of natural rewards: relevance to addictive drugs. J Neurosci 22: 3306-3311.

Kelz MB, Chen J, Carlezon Jr WA, Whisler K, Gilden L, Beckmann $\mathrm{AM}$ et al (1999). Expression of the transcription factor deltaFosB in the brain controls sensitivity to cocaine. Nature 401: 272-276.

Khan J, Bittner ML, Chen Y, Meltzer PS, Trent JM (1999). DNA microarray technology: the anticipated impact on the study of human disease. Biochim Biophys Acta 1423: M17-M28.

Khroyan TV, Barrett-Larimore RL, Rowlett JK, Spealman RD (2000). Dopamine D1- and D2-like receptor mechanisms in relapse to cocaine-seeking behavior: effects of selective antagonists and agonists. J Pharmacol Exp Ther 294: 680-687.

Koob GF (1992). Drugs of abuse: anatomy, pharmacology and function of reward pathways. Trends Pharmacol Sci 13: 177-184.

Koob GF, Sanna PP, Bloom FE (1998). Neuroscience of addiction. Neuron 21: 467-476.

Leshner AI (1997). Addiction is a brain disease, and it matters. Science 278: 45-47.

Lipshutz RJ, Fodor SP, Gingeras TR, Lockhart DJ (1999). High density synthetic oligonucleotide arrays. Nat Genet Suppl 21: $20-24$.

Lisman J, Schulman H, Cline H (2002). The molecular basis of CaMKII function in synaptic and behavioural memory. Nat Rev Neurosci 3: 175-190.

Logan SK, Garabedian MJ, Campbell CE, Werb Z (1996). Synergistic transcriptional activation of the tissue inhibitor of metalloproteinases-1 promoter via functional interaction of AP-1 and Ets-1 transcription factors. J Biol Chem 271: 774-782.

Ma Q, Jones D, Borghesani PR, Segal RA, Nagasawa T, Kishimoto T et al (1998). Impaired B-lymphopoiesis, myelopoiesis, and derailed cerebellar neuron migration in CXCR4- and SDF-1deficient mice. Proc Natl Acad Sci USA 95: 9448-9453.

Matsumoto RR, McCracken KA, Pouw B, Zhang Y, Bowen WD (2002). Involvement of sigma receptors in the behavioral effects of cocaine: evidence from novel ligands and antisense oligodeoxynucleotides. Neuropharmcol 42: 1043-1055.

McClung CA, Nestler EJ (2003). Regulation of gene expression and cocaine reward by CREB and DeltaFosB. Nat Neurosci 6: $1208-1215$.

Miner LL, Drago J, Chamberlain PM, Donovan D, Uhl GR (1995). Retained cocaine conditioned place preference in D1 receptor deficient mice. Neuroreport 6: 2314-2316.

Missale C, Nash SR, Robinson SW, Jaber M, Caron MG (1998). Dopamine receptors: from structure to function. Physiol Rev 78: 189-225.

Moratalla R, Xu M, Tonegawa S, Graybiel AM (1996). Cellular responses to psychomotor stimulant and neuroleptic drugs are 
abnormal in mice lacking the D1 dopamine receptor. Proc Natl Acad Sci USA 93: 14928-14933.

Morgan JI, Curran T (1991). Stimulus-transcription coupling in the nervous system: involvement of the inducible proto-oncogenes fos and jun. Annu Rev Neurosci 14: 421-451.

Murphy LJ (1998). Insulin-like growth factor-binding proteins: functional diversity or redundancy? J Mol Endocrinol 21: 97-107.

Nazarian A, Russo SJ, Festa ED, Kraish M, Quinones-Jenab V (2004). The role of D1 and D2 receptors in the cocaine conditioned place preference of male and female rats. Brain Res Bull 63: 295-299.

Nestler EJ (2000). Genes and addiction. Nat Genet 26: 277-281.

Nestler EJ (2001). Molecular basis of long-term plasticity underlying addiction. Nat Rev Neurosci 2: 119-128.

Nestler EJ, Kelz MB, Chen J (1999). DeltaFosB: a molecular mediator of long-term neural and behavioral plasticity. Brain Res 835: 10-17.

Pruitt DL, Bolanos CA, McDougall SA (1995). Effects of dopamine D1 and D2 receptor antagonists on cocaine-induced place preference conditioning in preweanling rats. Eur J Pharmacol 283: 125-131.

Ritz MC, Lamb RJ, Goldberg SR, Kuhar MJ (1987). Cocaine receptors on dopamine transporters are related to self-administration of cocaine. Science 237: 1219-1223.

Robinson TE, Berridge KC (1993). The neural basis of drug craving: an incentive-sensitization theory of addiction. Brain Res Brain Res Rev 18: 247-291.

Robinson TE, Kolb B (1999). Alterations in the morphology of dendrites and dendritic spines in the nucleus accumbens and prefrontal cortex following repeated treatment with amphetamine or cocaine. Eur J Neurosci 11: 1598-1604.

Romieu P, Martin-Fardon R, Bowen WD, Maurice T (2003). Sigma 1 receptor-related neuroactive steroids modulate cocaine-induced reward. J Neurosci 23: 3572-3576.

Self DW, Barnhart WJ, Lehman DA, Nestler EJ (1996). Opposite modulation of cocaine-seeking behavior by D1- and D2-like dopamine receptor agonists. Science 271: 1586-1589.

Sibley DR, Monsma FJJ, Shen Y (1993). Molecular neurobiology of dopaminergic receptors. Int Rev Neurobiol 35: 391-415.

Tang WX, Fasulo WH, Mash DC, Hemby SE (2003). Molecular profiling of midbrain dopamine regions in cocaine overdose victims. J Neurochem 85: 911-924.

Tao W, Pennica D, Xu L, Kalejta RF, Levine AJ (2001). Wrch-1, a novel member of the Rho gene family that is regulated by Wnt-1. Genes Dev 15: 1796-1807.

Taymans J, Leysen JE, Langlois X (2003). Striatal gene expression of RGS2 and RGS4 is specifically mediated by dopamine D1 and D2 receptors: clues for RGS2 and RGS4 functions. J Neurochem 84: $1118-1127$.

Tella SR (1994). Differential blockade of chronic versus acute effects of intravenous cocaine by dopamine receptor antagonists. Pharmacol Biochem Behav 48: 151-159.

Toda S, McGinty JF, Kalivas PW (2002). Repeated cocaine administration alters the expression of genes in corticolimbic circuitry after a 3-week withdrawal: a DNA macroarray study. J Neurochem 82: 1290-1299.

Tzschentke TM (1998). Measuring reward with the conditioned place preference paradigm: a comprehensive review of drug effects, recent progress and new issues. Prog Neurobiol 56: 613-672.

Ujike H, Kuroda S, Otsuki S (1996). Sigma receptor antagonists block the development of sensitization to cocaine. Eur $J$ Pharmacol 296: 123-128.

Vanderschuren LJ, Kalivas PW (2000). Alterations in dopaminergic and glutamatergic transmission in the induction and expression of behavioral sensitization: a critical review of preclinical studies. Psychopharmacology 151: 99-120.

Vincent VA, DeVoss JJ, Ryan HS, Murphy Jr GM (2002). Sigma receptor antagonists block the development of sensitization to cocaine. J Neurosci Res 69: 578-586.

White FJ, Kalivas PW (1998). Neuroadaptations involved in amphetamine and cocaine addiction. Drug Alcohol Depend 51: 141-153.

Xu M, Guo Y, Vorhees CV, Zhang J (2000). Behavioral responses to cocaine and amphetamine administration in mice lacking the dopamine D1 receptor. Brain Res 852: 198-207.

$\mathrm{Xu} \mathrm{M}, \mathrm{Hu}$ XT, Cooper DC, Moratalla R, Graybiel AM, White FJ et al (1994a). Elimination of cocaine-induced hyperactivity and dopamine-mediated neurophysiological effects in dopamine D1 receptor mutant mice. Cell 79: 945-955.

Xu M, Moratalla R, Gold LH, Hiroi N, Koob GF, Graybiel AM et al (1994b). Dopamine D1 receptor mutant mice are deficient in striatal expression of dynorphin and in dopamine-mediated behavioral responses. Cell 79: 729-742.

Yao WD, Gainetdinov RR, Arbuckle MI, Sotnikova TD, Cyr M, Beaulieu JM et al (2004). Identification of PSD-95 as a regulator of dopamine-mediated synaptic and behavioral plasticity. Neuron 41: 625-638.

Yoshimura Y, Aoi C, Yamauchi T (2000). Investigation of protein substrates of $\mathrm{Ca}(2+) /$ calmodulin-dependent protein kinase II translocated to the postsynaptic density. Mol Brain Res 81: 118-128.

Yuferov V, Kroslak T, Laforge KS, Zhou Y, Ho A, Kreek MJ (2003). Differential gene expression in the rat caudate putamen after 'binge' cocaine administration: advantage of triplicate microarray analysis. Synapse 48: 157-169.

Zhang D, Zhang L, Lou DW, Nakabeppu Y, Zhang J, Xu M (2002). The dopamine D1 receptor is a critical mediator for cocaine-induced gene expression. J Neurochem 82: $1453-$ 1464.

Zhang L, Lou D, Jiao H, Zhang D, Wang X, Xia Y et al (2004). Cocaine-induced intracellular signaling and gene expression are oppositely regulated by the dopamine D1 and D3 receptors. J Neurosci 24: 3344-3354.

Zhong H, Neubig RR (2001). Regulator of G protein signaling proteins: novel multifunctional drug targets. J Phar Exp Ther 297: 837-845.

Zumkeller W, Westphal M (2001). The IGF/IGFBP system in CNS malignancy. Mol Pathol 54: 227-229.

\section{Supplementary information accompanies the paper on Neuropsychopharmacology website (http://www.nature.com/npp)}

